\title{
Neuroprotective Effects of Quercetin in Alzheimer's Disease
}

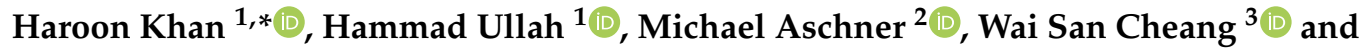 \\ Esra Küpeli Akkol 4 (iD) \\ 1 Department of Pharmacy, Abdul Wali Khan University, Mardan 23200, Pakistan; hamm.swabian@gmail.com \\ 2 Department of Molecular Pharmacology, Albert Einstein College of Medicine, Forchheimer 209, \\ 1300 Morris Park Avenue, Bronx, NY 10461, USA; michael.aschner@einstein.yu.edu \\ 3 Institute of Chinese Medical Sciences, State Key Laboratory of Quality Research in Chinese Medicine, \\ University of Macau, Macau, China; annacheang@um.edu.mo \\ 4 Department of Pharmacognosy, Faculty of Pharmacy Gazi University, 06330 Etiler/Ankara, Turkey; \\ esrak@gazi.edu.tr \\ * Correspondence: hkdr2006@gmail.com or haroonkhn@awkum.edu.pk; Tel.: +92-332-9123171
}

Received: 14 November 2019; Accepted: 22 December 2019; Published: 30 December 2019

\begin{abstract}
Quercetin is a flavonoid with notable pharmacological effects and promising therapeutic potential. It is widely distributed among plants and found commonly in daily diets predominantly in fruits and vegetables. Neuroprotection by quercetin has been reported in several in vitro studies. It has been shown to protect neurons from oxidative damage while reducing lipid peroxidation. In addition to its antioxidant properties, it inhibits the fibril formation of amyloid- $\beta$ proteins, counteracting cell lyses and inflammatory cascade pathways. In this review, we provide a synopsis of the recent literature exploring the relationship between quercetin and cognitive performance in Alzheimer's disease and its potential as a lead compound in clinical applications.
\end{abstract}

Keywords: quercetin; polyphenols; Alzheimer's disease; mechanistic insights; clinical directions

\section{Introduction}

Alzheimer's disease (AD) contributes to $60-80 \%$ of total dementia cases, and it mostly affects elder people (65 years of age or older) [1]. The pathogenesis of AD is typically associated with the accumulation of amyloid- $\beta(A \beta)$ aggregates and the hyperphosphorylation of tau proteins, leading to neurofibrillary tangles (NFTs) and synaptic dysfunction [2-4]. Around 35.6 million people worldwide are estimated to be affected with $\mathrm{AD}$, with a prevalence rate of 4.6 million new cases each year. The prevalence rate of $\mathrm{AD}$ increases with age: the rate doubles every 5 years from 60 years of age $[5,6]$.

Early studies led to the cholinergic deficit hypothesis of AD, which states that deficiency in acetylcholine is the main cause of the disease. In the pursuit of drugs that are able to restore acetylcholine levels, the first acetyl cholinesterase inhibitors were developed, including tacrine. Since then, other drugs in the same class have been pursued, namely donepezil, rivastigmine, and galantamine. Current AD therapy consists of cholinesterase inhibitors and $N$-methyl-D-aspartate (NMDA) antagonists, including memantine. Acetyl cholinesterase inhibitors prevent the hydrolysis of acetylcholine, and memantine modulates NMDA receptor activity, causing a reduction in excitatory glutamate signals. However, these drugs offer little palliative effects, and they also have numerous undesirable safety profiles with a number of adverse side effects $[7,8]$. Acetyl cholinesterase inhibitors are associated with gastrointestinal side effects such as nausea, diarrhea, and abdominal pain, as well as urinary incontinence, insomnia, and nightmares. The use of tacrine has been limited because of its poor bioavailability and reported hepatotoxicity. Memantine is clinically less effective compared 
to acetyl cholinesterase inhibitors. Additionally, these drugs are not targeting the root cause of the disorder [9].

Phytochemicals are best known to reduce the risk of chronic diseases, such as cardiovascular diseases, hypertension, diabetes, and cancers [10-12]. Flavonoids are the most diverse group of phytochemicals and are widely distributed in higher plants with outstanding therapeutic potential [13-16]. Flavonoids are further divided into six classes on the basis of their chemical skeleton: flavanols, flavanones, flavones, flavonols, isoflavonoids, and anthocyanidins [17]. While targeting multiple targets, they have been proven beneficial in the prevention of neurodegenerative disorders and may delay the process of neurodegeneration [18]. Flavonoids are extensively studied for their antioxidant and anti-inflammatory activities, both of which are important in triggering the pathogenesis of AD [19]. Studies suggested that flavonoids are capable of crossing the blood-brain barrier (BBB), which makes them potential agents in preventing neurodegenerative disorders; however, different flavonoid subclasses differ in their ability to cross the BBB $[20,21]$. In the case of AD, their efficacy is attributed to the reduction of $A \beta$ toxicity and decreasing oxidative stress [22,23]. Nevertheless, anti-AD effects of certain flavonoids, such as myricetin, rutin, fisetin, catechins, quercetin, kaempferol, and apigenin have been reported [24-27].

Quercetin is one of the most potent antioxidants of plant origin and is one of the predominant flavonoids found more commonly in edible plants [28]. It belongs to the flavonols class of flavonoids, representing a major class of polyphenols. The dietary intake of total flavonoids is estimated to be $200-350 \mathrm{mg} /$ day, and the intake of quercetin is $10-16 \mathrm{mg} /$ day. The recommended dosage of quercetin aglycone as a dietary supplement is $1 \mathrm{~g} /$ day [29-31]. It exhibits numerous beneficial effects on human health, acting as anti-carcinogenic, anti-inflammatory, anti-infective, and psychostimulant agent. It also inhibits lipid peroxidation and platelet aggregation, and it stimulates mitochondrial biogenesis [32]. Several studies have reported on the neuroprotective effects of quercetin, both in vitro and in vivo models of neurodegenerative disorders, such as cognitive impairment [33], ischemia, traumatic injury [34], Parkinson's disease (PD) [35], and Huntington's disease (HD) [36]. The aim of the present review is to provide a summary of the recent literature exploring the relationship between quercetin and cognitive performance. Our primary focus is on the chemical basis and pharmacology of quercetin and its anti-AD mechanisms.

\section{Chemistry of Quercetin}

A flavonoid is structurally diphenyl propane containing 15 carbon atoms in its structure (Figure 1A). It contains a close heterocyclic pyran ring in addition to two benzene rings. The term 4-oxo-flavonoid (Figure 1B) is often used to describe flavonoid containing a carbonyl group on position C-4 of ring C. Substitution and oxidation in the heterocyclic pyran ring classifies flavonoids into subclasses, namely flavones, flavonols, flavanones, flavononol, isoflavones, and flavan-3-ols. Substitution in the benzene rings of flavonoid structures leads to differences in individual compounds within specific classes [37,38]. Quercetin belongs to the flavone class of flavonoids having a chemical formula of $\mathrm{C}_{15} \mathrm{H}_{10} \mathrm{O}_{7}$. Its IUPAC name is $3,3^{\prime}, 4^{\prime}, 5,7$-pentahydroxyflavanone or 3,3', $4^{\prime}, 5,7$-pentahydroxy-2-phenylchromen-4-one (Figure 2). Quercetin contains an $\mathrm{OH}$ group at positions $3,5,7,3^{\prime}$, and $4^{\prime}$. Quercetin is an aglycone, (lacking an attached sugar molecule). Attaching a glycosyl group (glucose, rhamnose, or rutinose) most commonly at position 3 replacing the $\mathrm{OH}$ group leads to the formation of quercetin glycoside. Quercetin is insoluble or sparingly soluble in water, while it is quite soluble in alcohol and lipids. A glycosyl group increases its water solubility, and thus the quercetin glycoside is soluble in water [32,39]. In addition to antioxidant activities, multiple $\mathrm{OH}$ groups in the structure of quercetin may also lead to its photodegradation. Dall'Acqua et al. (2012) reported that $\mathrm{OH}$ groups at positions $3,3^{\prime}$, and $4^{\prime}$ are mainly involve in photolability, while $\mathrm{OH}$ groups at positions 5 and 7 do not play a crucial role in the photo-oxidative mechanism [40]. 
<smiles>c1ccc(C2CCc3ccccc3O2)cc1</smiles>

(A)<smiles>O=c1cc(-c2ccccc2)oc2ccccc12</smiles>

(B)

Figure 1. (A) Flavan nucleus, (B) 4-oxo-flavonoid nucleus.<smiles>O=c1c(O)c(-c2ccc(O)c(O)c2)oc2cc(O)cc(O)c12</smiles>

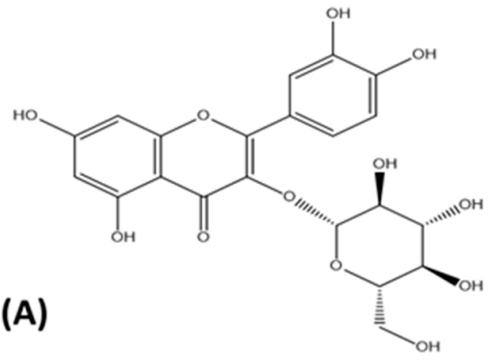<smiles>C[C@@H]1[C@H](Oc2c(-c3ccc(O)c(Cl)c3)oc3cc(O)cc(O)c3c2=O)O[C@H](C(=O)O)[C@@H](O)[C@H]1O</smiles>

\section{Quercetin}<smiles>O=c1c(OS(=O)(=O)O)c(-c2ccc(O)c(O)c2)oc2cc(O)cc(O)c12</smiles><smiles>COc1c(-c2ccc(O)c(O)c2)oc2cc(O)cc(O)c2c1=O</smiles>

(D)

Figure 2. Chemical skeleton of quercetin and derivatives. (A) Quercetin glucoside, (B) quercetin-3-O-sulfate,

(C) quercetin-3-O-glucuronide, and (D) 3-O-methyl quercetin.

Several flavonoids have anti-inflammatory activity, among which flavanones such as naringenin have weak activity, while flavonols including quercetin, kaempferol, and myricetin have strong anti-inflammatory activity. Flavonols are more active against phospholipase A-2, given the presence of the C-ring-2,3 double bond. Furthermore, the glycosylation of quercetin, such as rutin, reduces the anti-inflammatory activity of quercetin [41]. Glycosylation at position 3 of quercetin leads to a decrease in the free radical neutralizing activity. Glycosylation also decreases the acetyl cholinesterase inhibition activity of quercetin [42]. The methylation of quercetin at positions $4^{\prime}$ and 7 results in improved 
anticancer activities. The replacement of $\mathrm{OH}$ groups with $\mathrm{O}$-methylated moieties also increases the metabolic stability of a compound [43]. The presence of a double bond between C2 and C3 as well as the $\mathrm{OH}$ group at ring $\mathrm{B}$ is essential for the thrombin inhibition activity of quercetin. Substituting the $\mathrm{OH}$ group with an $\mathrm{OCH}_{3}$ group in ring $\mathrm{B}$ and ring $\mathrm{C}$ reduces the thrombin inhibition activity, whereas replacement of the $\mathrm{OH}$ groups in ring $\mathrm{A}$ with an $\mathrm{OCH}_{3}$ group improves the thrombin inhibition activity of quercetin [44].

Quercetin may act as a pro-oxidant phytochemical by generating reactive oxygen species (ROS) and reactive electrophilic quinine type metabolites because of the presence of catechol moiety in the $\mathrm{B}$ ring, C-ring-2, 3 double bond, and free $\mathrm{OH}$ group at the C-3 position [45]. Furthermore, in vitro studies have confirmed that the esters-based precursors of quercetin increase the bioavailability of quercetin [46]. In considering the general structure of flavonoids, $\mathrm{OH}$ group substitution at positions $\mathrm{C} 5, \mathrm{C} 7$, and $\mathrm{C} 3$, the substitution of $\mathrm{OCH}_{3}$ or $\mathrm{H}$ at $\mathrm{C}^{\prime}$, and $\mathrm{OH}$ or $\mathrm{OCH}_{3}$ substitution at position $\mathrm{C}^{\prime}$ ' improve their neuroprotective activities as confirmed by in vitro studies, utilizing neuronal cell cultures [47].

\section{Sources}

The name quercetin has been used since 1857. It is derived from Latin Quercetum, after Quercus (oak) [48]. It is a flavonoid that is most commonly occurring in higher plants and in the glycosidal form, such as rutin (quercetin-3-O-rutinoside), isoquercetin (quercetin-3-O-glucoside), and hyperin (quercetin-3-O-galactoside). It can also be isolated in free-form from leaf surfaces, fruits, or bud extracts. Plant families rich in quercetin are Compositae, Passiflorae, Rhamnaceae, and Solanaceae [49]. Onions, asparagus, red leaf lettuce, apples, capers, and berries contain relatively high concentrations of quercetin $[29,50]$.The botanical sources of quercetin have been summarized in Table 1.

Table 1. Botanical sources of quercetin.

\begin{tabular}{|c|c|c|c|c|c|}
\hline S.No. & Botanical Name & Family & Common Name & Active Parts & References \\
\hline 01 & Punica granatum & Lythraceae & Pomegranate & Fruits & {$[51]$} \\
\hline 02 & Ruta graveolens & Rutaceae & Rue & Leaves & {$[51]$} \\
\hline 03 & Camellia sinensis & Theaceae & Green tea & Leaves & {$[52,53]$} \\
\hline 04 & Allium cepa & Amaryllidaceae & Red onion & Fruits & {$[54,55]$} \\
\hline 05 & Mangifera indica & Anacardiaceae & Mango & Fruits & {$[56]$} \\
\hline 06 & Moringa oleifera & Moringaceae & Drumstick tree & Leaves & {$[57,58]$} \\
\hline 07 & Cydonia oblonga & Rosaceae & Quince & Fruits and leaves & [59] \\
\hline 08 & Solidago canadensis L. & Compositae/ Asteraceae & Goldenrod & Flowering parts & {$[60]$} \\
\hline 09 & $\begin{array}{l}\text { Vaccinium angustifolium and } \\
\text { Vaccinium corymbosum }\end{array}$ & Ericaceae & Blueberries & Fruits & {$[61,62]$} \\
\hline 10 & Phaleria macrocarpa & Thymelaceae & Mahkotadewa & Seeds & {$[63]$} \\
\hline 11 & Lepidium latifolium & Brassicaceae & Papperweed & Roots and leaves & {$[64,65]$} \\
\hline 12 & Achras sapota (Manilkara zapota) & Sapotaceae & Sapodilla & Fruits & {$[66]$} \\
\hline 13 & Cichorium intybus & Compositae/ Asteraceae & Chicory & Leaves & {$[67]$} \\
\hline 14 & Solanum lycopersicum & Solanaceae & Tomato & Fruits & {$[68]$} \\
\hline 15 & Malus domestica & Rosaceae & Apple & Fruits & [69] \\
\hline 16 & Vitis vinifera & Vitaceae & Grapevines & Fruits & {$[70,71]$} \\
\hline 17 & Rhamnus alaternus & Rhamnaceae & Buckthorn & Bark & {$[72]$} \\
\hline 18 & Passiflora incarnate & Passifloraceae & Passion flower & Leaves & {$[73]$} \\
\hline 19 & Morus alba & Moraceae & White mulberry or Tut & Leaves & {$[74,75]$} \\
\hline 20 & Ginkgo biloba & Ginkgoaceae & Maidenhair tree & Leaves & {$[76,77]$} \\
\hline 21 & Hypericum perforatum & Hypericaceae & $\begin{array}{l}\text { St. John's wort or } \\
\text { hypericum }\end{array}$ & Aerial parts & {$[78]$} \\
\hline 22 & Achillea millefolium L. & Compositae/ Asteraceae & Yarrow & Flowering tops & [79] \\
\hline
\end{tabular}




\section{Pharmacokinetic Parameters of Quercetin}

Studies have revealed that the low bioavailability of quercetin limits its use for therapeutic purposes, although it has a wide range of pharmacological properties. Low solubility, poor absorption, and rapid metabolism are major aspects of the low bioavailability of quercetin [80]. Ader et al. (2000) have explored the bioavailability and metabolism of quercetin in pigs [81]. Quercetin was administered to each animal in a single intravenous dose of $0.4 \mathrm{mg} / \mathrm{kg}$ body weight and a single oral dose of $50 \mathrm{mg} / \mathrm{kg}$ body weight one week later. Blood samples were collected to analyze the pharmacokinetic parameters of quercetin. The apparent bioavailability was $0.54 \pm 0.19 \%$ when considering free quercetin alone, $8.6 \pm 3.8 \%$ including conjugated quercetin, and $17.0 \pm 7.1 \%$ including quercetin metabolites (kaempferol, tamarixetin, and isorhamnetin). The authors also reported that the conjugation of quercetin to glucuronic acid and sulfuric acid preferentially occurs in the intestinal wall.

Moon et al. (2008) have studied the pharmacokinetics of quercetin in human beings [82]. Quercetin was administered to subjects in doses of $500 \mathrm{mg}$ three times daily, and the plasma and urine samples were collected from subjects to analyze the concentration of quercetin aglycone and metabolites. The average peak plasma concentration reported after the administration of quercetin at $500 \mathrm{mg}$ three times daily was $463 \mathrm{ng} / \mathrm{mL}$ at $3.5 \mathrm{~h}$. Re-entry peaks on plasma concentration versus time curves showed enterohepatic recirculation. The oral clearance of quercetin was reported to be high $\left(3.5 \times 10^{4} \mathrm{~L} / \mathrm{h}\right)$ with an average half life of $3.5 \mathrm{~h}$. The urinary recovery of quercetin aglycone and conjugated metabolites were $0.05 \%$ to $3.6 \%$ and $0.08 \%$ to $2.6 \%$, respectively. Previously, Day et al. (2001) while studying the identification of quercetin metabolites in plasma have reported that quercetin is found exclusively as a glucuronated or sulfate conjugate in plasma after oral administration [83].

Moreover, quercetin aglycone is less effective to cross the BBB, as it is a substrate for efflux transporter p-glycoprotein. On the other hand, quercetin conjugates are also predicted to less effectively cross the BBB because of high polarity $[84,85]$. However, the literature supported that some glucuronides are effectively crossing the BBB because of aided active transport [86]. Kawei et al. (2008) revealed that at sites of inflammation, the intracellular deconjugation of quercetin 3-O-glucuronide by $\beta$-glucuronidase increases, and this phenomena is more relevant inside the central nervous system (CNS) in the case of neurodegenerative disorders, rather than being of relevance in the penetration of the BBB [87].

\section{Pathophysiological Mechanisms of Alzheimer's Disease}

$\mathrm{AD}$ is mainly characterized by the accumulation of extracellular amyloid plaques, which are known as senile plaques. The amyloid plaques are associated with neuroinflammatory changes as well as neurofibrillary tangles, affecting processes that are essential in maintaining neuronal health: communication, metabolism, and repair. $A \beta$ is produced by the sequential cleavage of amyloid $\beta$ precursor protein by $\beta$ and $\gamma$ secretases $[88,89]$. The amyloid precursor protein (APP) exists in three different forms: the shortest isoform, APP695 mostly expressed in neurons, whereas two other isoforms APP751 and APP770 are expressed in glial cells, such as astrocytes. The physiological role of APP is to stimulate cell growth and proliferation. A $\beta$ plaques lead to neuronal loss in several brain regions, including the entorhinal cortex, hippocampus, neocortex, amygdale, and subcortical areas [90,91]. Two different enzymatic processes of APP occur in the cells: the non-amyloidogenic and the amyloidogenic pathways. In the non-amyloidogenic processing pathway, the APP is cleaved by $\alpha$ and $\gamma$-secretases, which yields long secreted forms of APP (sAPP $\alpha)$ and C-terminal fragments. In the amyloidogenic processing pathway, APP is cleaved by $\beta$ and $\gamma$-secretases, which yields long secreted forms of APP (sAPP $\beta$ ), C-terminal fragments, and A $\beta$ s. The A $\beta$ fragment is chemically sticky-forming plaques, and blocks cell-to-cell signaling via synapses, in turn leading to neuronal cell death $[92,93]$.

Neurofibrillary tangles (NFTs) are produced by the hyperphosphorylation of microtubule-associated proteins, which are known as tau [94], representing another key feature of AD. The excessive phosphorylation of tau proteins decreases their binding ability to microtubules, resulting in the formation of NFTs [95]. Both the density and neuroanatomic localization of NFTs are important determinants in the pathogenesis of AD. NFTs in neocortical regions are commonly associated with 
severe cognition impairment [96]. $A \beta$ induces the phosphorylation of tau proteins, thus triggering the formation of NFTs and causing neuronal cell death by increasing oxidative stress, altering calcium homeostasis and excitotoxicity [90]. Imbalance between $A \beta$ production and clearance leads to the formation of $A \beta$ aggregates, especially in late onset $A D$. The impairment of $A \beta$ clearance most commonly occurs in late onset AD. Heparan sulfate proteoglycans (HSPGs) are most critical in the pathogenesis of $A D$ by affecting $A \beta$ metabolism and decreasing $A \beta$ clearance. HSPGs bind to $A \beta$ and accelerate its aggregation, mediating the neurotoxicity and neuroinflammation induced by $\mathrm{A} \beta$. Under normal conditions, HSPGs perform various important physiological functions in development, growth factor signaling, cell proliferation, adhesion, migration, and homeostasis [97].

Oxidative stress commonly occurs in $\mathrm{AD}$, contributing to neurodegeneration. ROS generation triggers $A \beta$ aggregation. Oxidative stress is inherent to mild cognitive impairment (MCI) in the progression of AD. Patients with MCI usually develop cognitive impairment with a minimal impairment of instrumental activities of daily life, and it can be the first cognitive expression of AD. Alteration in the phosphorylation of proteins, such as heme oxygenase- 1 and biliverdin reductase $\mathrm{A}$, has been noted to occur, affecting the signaling of the most critical antioxidant pathways [98-100]. This leads to mitochondrial damage, which is concomitant with the decreased activity of mitochondrial energy-related proteins, including pyruvate dehydrogenase complex and alpha-ketoglutarate dehydrogenase. Defective mitochondria, in turn, trigger the generation of high levels of reactive oxygen species (ROS), for which antioxidant defenses may be deficient [101-103]. As such, the process proceeds unabated, as in a brush fire.

Neuroinflammation is a hallmark in the pathogenesis of AD. The innate immune cells of the brain are fast to respond to systemic events, mostly in aged and diseased brains. Misfolded and aggregated proteins binding to pattern recognition receptors on microglia and astroglia trigger an immune response, releasing a number of inflammatory cytokines and chemokines [104,105]. In contrast to oxidative stress, which is short lived, chronic inflammation is long lasting, resulting in the sustained release of inflammatory mediators.

Microglia surrounding senile plaques is commonly activated in $\mathrm{AD}$, resulting in the upregulation of human leukocyte antigen-DR (HLA-DR). In addition, the generation of inflammatory mediators may lead to microglial activation and neurotoxicity secondary to the CD14-dependent process. Despite having phagocytotic activity, microglia fail to phagocytose $A \beta$ due to the presence of inflammatory cytokines and various extracellular matrix proteins [106]. Receptor of advanced glycation end products (RAGE) activation leads to neurodegeneration as it triggers an increase in inflammatory mediators and oxidative stress. RAGE activation also leads to activation of downstream regulatory pathways such as the NF-kB, STAT, and JNK pathways [107].

Acetylcholinergic, glutamatergic, and serotonergic neurons are mostly affected in AD. Early histological changes involve the loss of cholinergic neurotransmission in the cerebral cortex. The latter, along with the hippocampus, receive the highest cholinergic input, and the loss of cholinergic neurons in these regions results in cognitive deficits and memory impairment. Choline acetyltransferase activity is greatly reduced in individuals with $\mathrm{AD}$. It has also been shown that acetyl cholinesterase (AChE) accelerates the aggregation of $A \beta$ [108]. The degeneration of serotonergic neurons in the raphe nucleus and noradrenergic neurons in the locus coeruleus mediates on cognitive symptoms associated with AD [109]. Figure 3 illustrates the pathogenesis of Alzheimer's disease. 


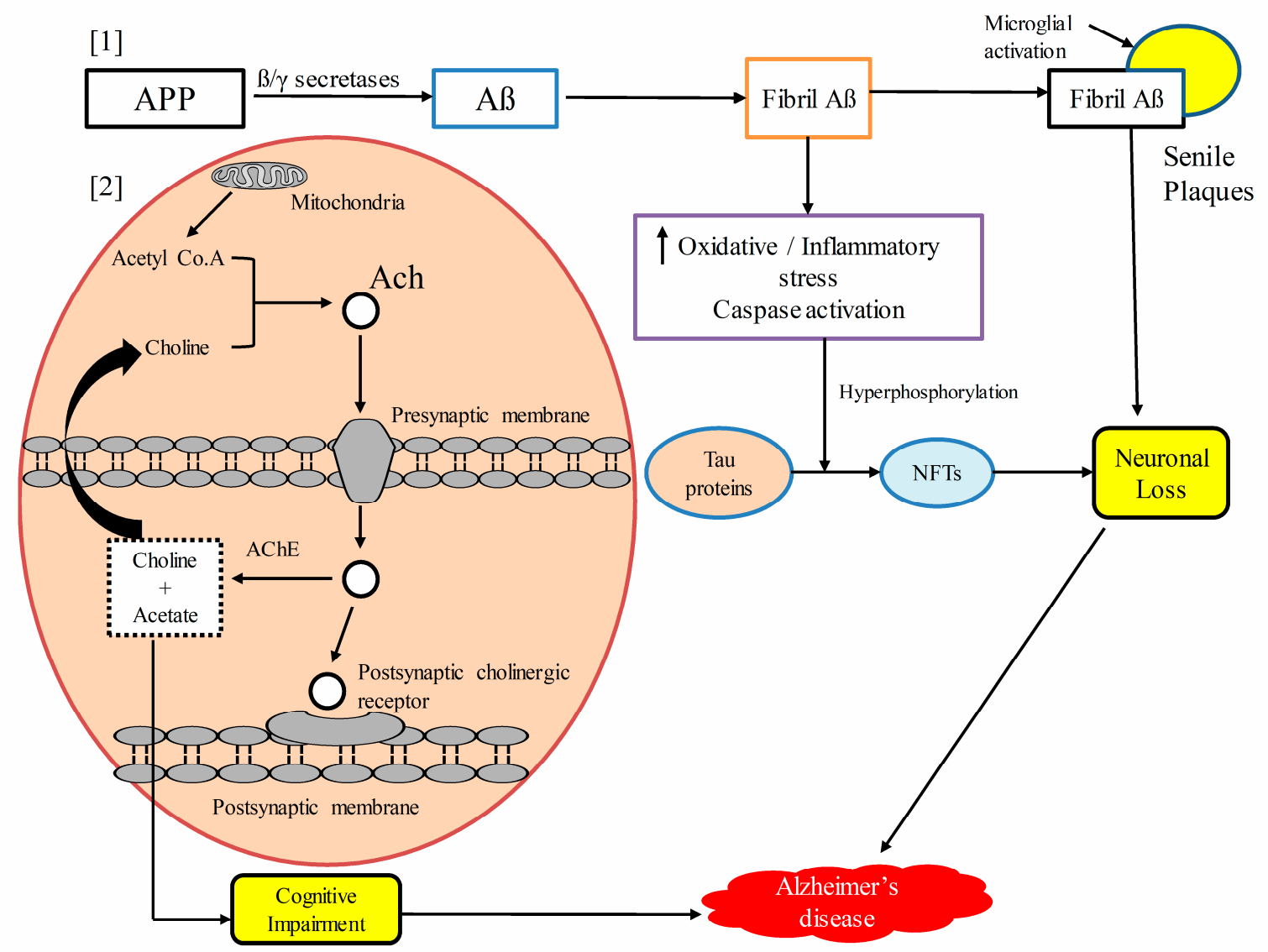

Figure 3. Schematic presentation of the pathogenesis of Alzheimer's disease. [1] Amyloid precursor protein (APP) is hydrolyzed by $\beta$ and $\gamma$ secretases to form $\beta$-amyloid (A $\beta$ ), which aggregates to form fibril A $\beta$ s. Fibril $A \beta s$ upregulate oxidative stress, the inflammatory cascade, and caspase activation, which results into the hyperphosphorylation of the Tau protein to form neurofibrillary tangles(NFTs), and the ultimate result is neuronal cells loss. Extensive fibrils along with activated microglia accumulated to form senile plaques, which lead to neuronal and synaptic loss. [2] Upstream regulating acetyl cholinesterase (AChE) enzyme promotes acetylcholine (Ach) degradation, resulting in neurotransmitter deficit, which leads to cognitive impairment. Amyloid precursor protein (APP), amyloid beta proteins $(A \beta)$, neurofibrillary tangles (NFTs), acetylcholine (Ach), acetyl cholinesterase (AChE).

\section{Neuroprotective Efficacy of Quercetin}

The neuroprotective effects of quercetin have been extensively studied. At low micromolar concentrations, it antagonizes cell toxicity by oxidative stress in neurons. It suppresses neuroinflammatory processes by downregulating pro-inflammatory cytokines, such as NF-kB and iNOS, while stimulating neuronal regeneration. After absorption, quercetin metabolites are glucuronated, methylated, or sulfated, and all have been shown to afford neuroprotection. The neuroprotective efficacy of quercetin has been studied in both in vitro and in vivo models $[50,110,111]$. A study using drug screening in Caenorhabditis elegans nematodes with neuronal expression of human exon-1 huntingtin (128Q) and mutant Htt striatal cells derived from knock-in HD mice, concluded that isoquercetin improved motor functions in acute spinal cord injury, reduced $\alpha$-synuclein fibrillization, reduced hippocampal neuronal cell death, improved synaptic plasticity, and reversed histopathological hallmarks of AD [112]. Quercetin also protects against mitochondrial dysfunction and progressive dopaminergic neurodegeneration by activating PKD1-Akt cell survival signaling axis Cell Culture and MitoPark transgenic mouse models of Parkinson's disease [113]. 
Quercetin has shown therapeutic efficacy, improving learning, memory, and cognitive functions in AD [114]. Khan et al. (2009) and Shimmyo et al. (2008) concluded that quercetin administration resulted in the inhibition of $\mathrm{AChE}$ and secretase enzymes using in vitro models, thus preventing the degradation of acetylcholine, and decreasing A $\beta$ production, respectively $[115,116]$. Sabogal-Guáqueta et al. (2015) have been reported that quercetin administration reverses extracellular $\beta$-amyloidosis and decreases tauopathies, astrogliosis, and microgliosis in the hippocampus and amygdale, thus protecting cognitive and emotional function in age triple transgenic Alzheimer's disease model mice [117]. Wand et al. (2014) studied the effects of the long-term administration of quercetin on cognition and mitochondrial dysfunction in a mouse model of Alzheimer's disease. They noted that quercetin ameliorates mitochondrial dysfunction by restoring mitochondrial membrane potential, decreases ROS production, and restores ATP synthesis. It also increased the expression of AMP-activated protein kinase (AMPK), which is a key cell regulator of energy metabolism. Activated AMPK can decrease ROS generation by inhibiting NADPH oxidase activity or by increasing the antioxidant activity of enzymes such as superoxide dismutase-2 and uncoupling protein-2. The activation of AMPK also decreased $A \beta$ deposition, regulating APP processing and promoting A $\beta$ clearance. These mechanisms likely account for some of the therapeutic efficacy of quercetin on cognition and the attenuation of $A \beta$-induced neurotoxicity [118]. Quercetin and rutin have also been reported to function as memory enhancers in scopolamine-induced memory impairment in zebrafish, thus possibly enhancing cholinergic neurotransmission [119].

\section{Anti-Alzheimer's Disease Mechanisms of Quercetin}

\subsection{Inhibition of A A Aggregation and Tau Phosphorylation}

The aggregation of $A \beta$ is a key hallmark of AD [120]. Quercetin interferes with the formation of neurotoxic oligomeric $A \beta$ species and displays fibril destabilizing effects on preformed fibrillar $A \beta$, reversing $A \beta$-induced neurotoxicity [110]. The structure of efficient polyphenolic inhibitors of $\mathrm{A} \beta$ contains two aromatic rings with two to six atom linkers. The aromatic rings contain a minimum number of three hydroxyl groups, which play an important role in fibril inhibition through hydrophobic interaction between the aromatic rings with $\beta$-sheet structures, forming hydrogen bonds. The phenolic hydroxyls increase the electron density in the aromatic rings, which may increase the binding of quercetin with the aromatic amino acids of the peptide beta-sheet structures. Quercetin possesses these structural requirements containing hydrophobic moieties and thus arrests fibril formation. The more hydroxyl groups present in the structure of the molecule, the higher its anti-amyloidogenic activity [121,122]. It is also suggested that the catechol structure may be auto-oxidized to form o-quinone on ring $\mathrm{B}$, which then forms an $\mathrm{O}$-quinone- $\mathrm{A} \beta 42$ adduct by targeting Lys residues at positions 16 and 28 of $A \beta 42$. This phenomenon explains why quercetin has higher $A \beta$ aggregation inhibitory activities compared to kaempferol, morin, and datiscetin [123].

Quercetin is also reported from in vitro and in silico studies to inhibit beta-secretase-1 (BACE-1) enzyme activity through the formation of hydrogen bonds. The OH group at position $\mathrm{C}-3$ has a significant role in BACE-1 inhibition [116]. It has been documented from in vitro and molecular docking studies performed by Paris et al. (2011) that NF-kB regulates the production of $A \beta$ by regulation of the $\beta$ cleavage of APP, and that the quercetin-induced inhibition of NF-kB affects the regulation of BACE-1 expression [124]. Tauopathy commonly begins in the hippocampus, affecting hippocampal-dependent cognitive tasks followed by progression to other brain areas. Quercetin has been shown to decrease the phosphorylation of tau proteins and to inhibit the formation of NFTs in age triple transgenic Alzheimer's disease model mice [117]. Kinases and protein phosphatases such as protein phosphatase 2A (PP2A) play a role in regulating the hyperphosphorylation of tau proteins. The hyperphosphorylation of tau proteins is mostly due to the imbalance between phosphorylation and dephosphorylation mechanisms. Thus, the inhibition of PP2A may lead to the hyperphosphorylation of tau proteins. Quercetin reverses 
the hyperphosphorylation of tau proteins via MAPKs and PI3K/Akt/GSK3 $\beta$ signaling pathways in HT22 cells (a cell line from mouse hippocampal neurons) [125].

\subsection{Acetylcholinesterase Inhibition}

The inhibition of $\mathrm{AChE}$ is one of the therapies most commonly pursued in the treatment of mild to moderate $\mathrm{AD}$. AChE is an enzyme that is responsible for the degradation of acetylcholine, and its inhibition results in increased acetylcholine levels, thus improving the cognitive symptoms of AD. In vitro studies have shown that quercetin is a competitive inhibitor of $\mathrm{AChE}$ and butyrylcholinesterase (BChE). It inhibits both enzymes in a concentration-dependent manner [126]. Quercetin inhibits AChE secondary to hydrophobic interactions and strong hydrogen bonding with the enzyme, reducing the hydrolysis of ACh, thus increasing ACh levels in the synaptic cleft, as reported by Abdalla et al. (2013) using cadmium-exposed rats as a model of study [127]. Studies have linked the presence/absence of $\mathrm{OH}$ groups on the phenyl rings of the test compound to the inhibition of $\mathrm{AChE}$ and $\mathrm{BChE}$, given that the $\mathrm{OH}$ groups form hydrogen bonds with amino acid residues at the active site of the enzyme. This phenomenon may explain the inhibitory efficacy of quercetin for both of these enzymes. Moreover, quercetin exhibits greater potency for the inhibition of $\mathrm{AChE}$ and $\mathrm{BChE}$ than its glycosidal form, rutin. Previous studies have posited the presence of a sugar moiety in the molecule is essential for its enzymatic inhibition $[115,128,129]$. Jung et al. (2007) studied the acetylcholinesterase inhibiting the potential of flavonoids, including quercetin isolated from Agrimonia pilosa and they reported the IC50 value of quercetin to be 19.8 [130].

\subsection{Attenuation of Oxidative Stress}

Oxidative stress is caused by the accumulation of ROS in cells, and is an important factor in various neurodegenerative disorders. It is the most common mechanism of age-related degenerative processes. Mitochondria are the primary site for ROS production, and mitochondrial dysfunction leads to the overproduction of ROS followed by ATP depletion and ultimately cell death $[50,131]$. The major source of ROS is the superoxide anion radicals generated by the electron transport chain during oxidative phosphorylation. Superoxide dismutase (SOD) converts superoxide ions to hydrogen peroxide, which can be detoxified by catalase and glutathione peroxidases [132]. It has been reported that $\mathrm{A} \beta$ triggers oxidative stress, leading to lipid peroxidation and protein oxidation, which results in damaged mitochondria and the dysfunction of key enzymes associated with various pathways, including glucose metabolism [133].

Among the phytochemicals, quercetin is a potent antioxidant. It has been shown to effectively reduce the concentrations of superoxide anion free radicals, and its antioxidant potential makes it a versatile choice in the management of various disorders, including AD [49]. Previous studies have shown that quercetin has direct radical scavenging action. The presence of two pharmacophores in its structure is responsible for its antioxidant activities: one is a catechol group in the B ring, and the other is the $\mathrm{OH}$ group at position C-3. Quercetin also modulates the cell's own antioxidant pathways, by inducing Nrf-2-ARE and paraoxonase 2 (PON2), which is an antioxidant enzyme. Nuclear factor (erythroid-derived 2)-like 2 (Nrf-2) is an important regulator of cellular defenses against oxidative stress. Heme oxygenase-1, glutamate cysteine ligase, glutathione S-transferase, glutathione peroxidase, SOD, catalase, sulfiredoxin, and thioredoxin are enzymes downstream of Nrf-2-ARE. Thus, the activation of the Nrf-2-ARE pathway likely modulates the formation and degradation of misfolded protein aggregates in $\mathrm{AD}[50,64,134]$.

\subsection{Attenuation of Neuroinflammation by Quercetin}

Reducing the neuroinflammatory events in microglia might afford a beneficial strategy for the prevention of the progression of inflammatory-mediated neurodegenerative disorders. Quercetin has been reported to have anti-inflammatory actions, and is a suitable candidate among phytochemicals for future studies on its efficacy to reverse neuroinflammation $[135,136]$. Quercetin has already been 
shown to inhibit neuroinflammation by reducing nitric oxide production, iNOS gene expression in microglia, the production of inflammatory cytokines such as tumor necrosis factor- $\alpha$ (TNF- $\alpha$ ), IFN- $\gamma$, interleukin-1 $\beta$ (IL-1 $\beta$ ), IL-6, IL-12, and COX-2 in activated macrophages, as well as a reduction in cytokine expression as reported from in vivo studies. Quercetin also downregulates JNK/Jun phosphorylation and inhibits TNF- $\alpha$ production in mice, thus protecting neurons against LPS-induced inflammation [137]. Figures 4 and 5 have been summarizing anti-Alzheimer's targets and mechanistic insights of quercetin, respectively.

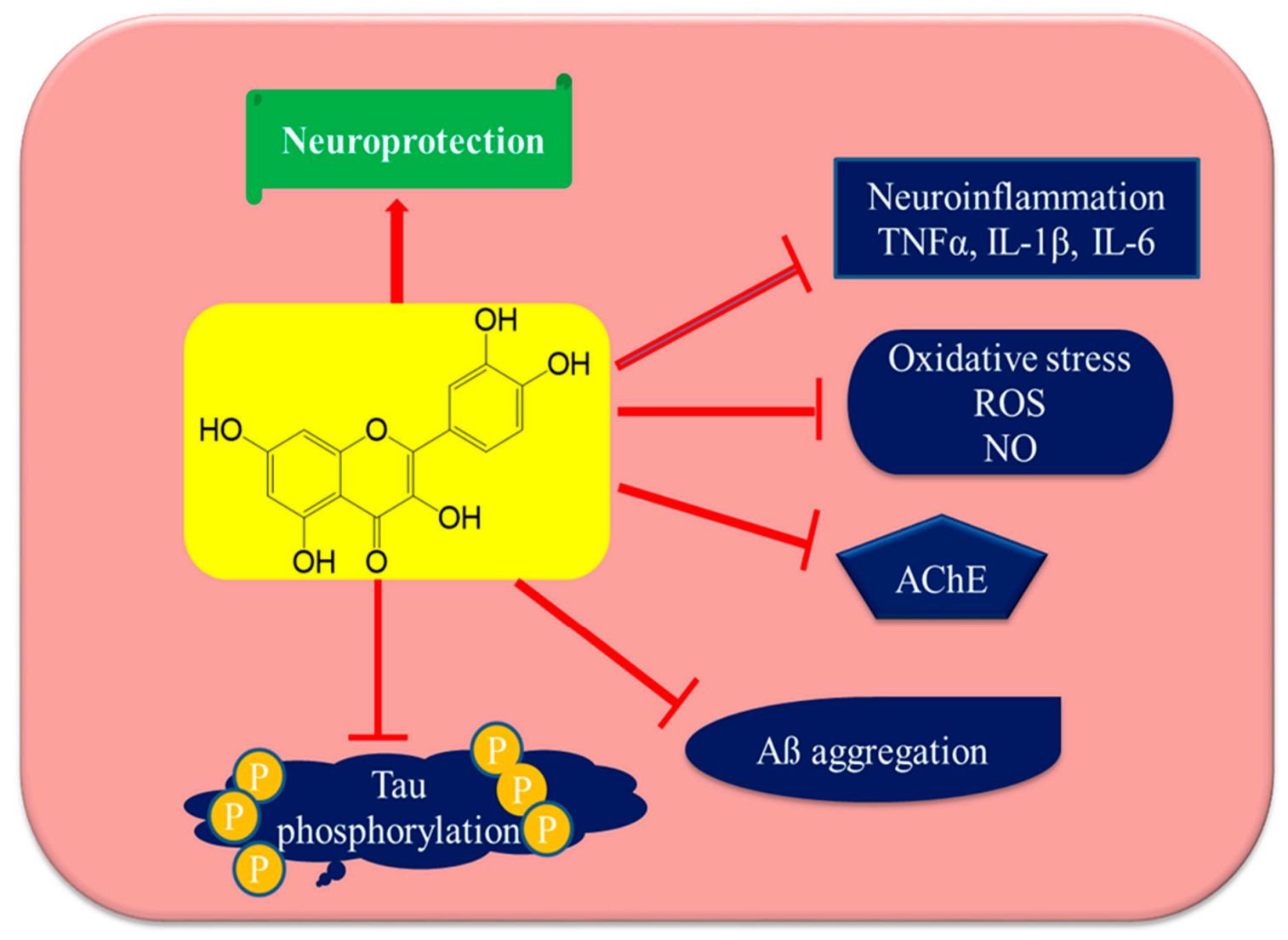

Figure 4. Anti-Alzheimer's disease targets of quercetin. Quercetin may utilize several mechanistic targets for neuroprotection in Alzheimer's disease such as the downstream regulation of oxidative stress and neuroinflammation, which leads to the direct protection of neurons, inhibiting AChE enzymes and resulting in increasing acetylcholine levels and reducing Tau phosphorylation and $A \beta$ aggregation. Tumor necrosis factor- $\alpha$ (TNF $\alpha$ ), interleukin-1 $\beta$ (IL-1 $\beta)$, interleukin-6 (IL-6), reactive oxygen species (ROS), nitric oxide (NO), acetyl cholinesterase (AChE), and amyloid beta protein $(A \beta)$. 


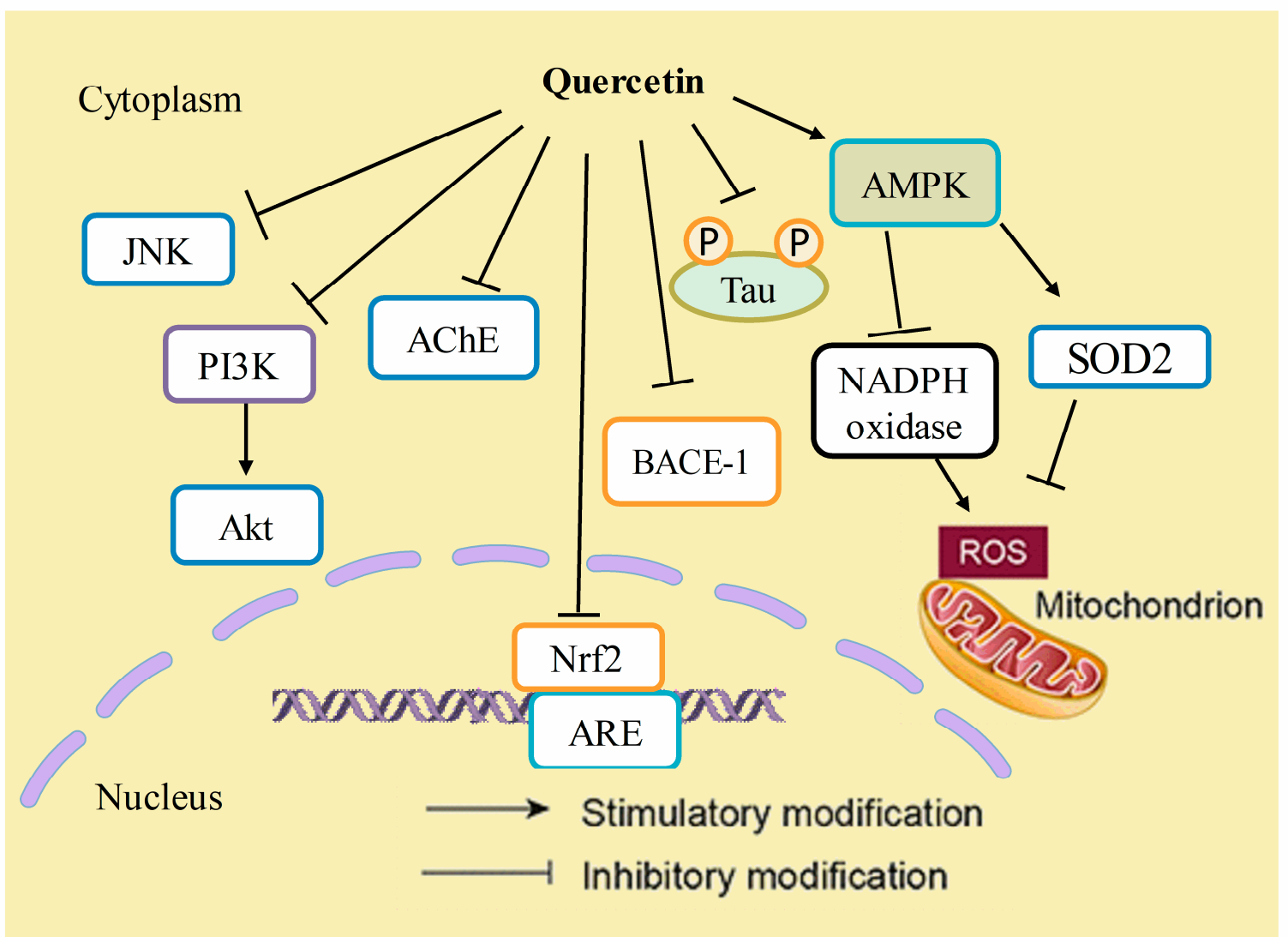

Figure 5. Mechanistic insights of quercetin in Alzheimer's disease. Quercetin has inhibitory effects on JNK, PI3K/Akt pathways, acetyl cholinesterase (AChE), nuclear factor (erythroid-derived 2)-like 2 (Nrf-2), beta-secretase-1 (BACE-1) enzyme activity, and the hyperphosphorylation of tau proteins. On the other hand, it stimulates the expression of AMP-activated protein kinase (AMPK), which thereby decreases reactive oxygen species (ROS) generation by inhibiting NADPH oxidase activity or by increasing the antioxidant activity of enzymes such as superoxide dismutase-2 (SOD2).

\section{Anti-Alzheimer's Disease Potential: In Vitro Studies on the Efficacy of Quercetin}

Quercetin protects neurons from oxidative damage, while reducing lipid peroxidation. Furthermore, given its antioxidant properties, quercetin inhibits the fibril formation of $A \beta$ proteins, counteracting cell lyses and inflammatory cascade pathways $[7,138,139]$. In vitro studies on quercetin have shown that its antioxidant activities are concentration-dependent. It acts as an antioxidant at lower concentrations (neuronal cells treated with $5 \mu \mathrm{M}$ and $10 \mu \mathrm{M}$ ), but it possesses toxic effects at higher doses (neuronal cells treated with $20 \mu \mathrm{M}$ and $40 \mu \mathrm{M}$ ) [140]. It also inhibits iNOS and regulates the expression of COX-2 in various models, reflecting upon its anti-inflammatory activities. Most of the absorbed quercetin is present as metabolites, including glucuronidated, methylated, and sulfated metabolites. All exert neuroprotective effects, but limited testing of these metabolites has been carried out to date [117]. It has also been reported that quercetin decreases APP maturation, thus altering A $\beta$ synthesis and aggregation [141]. The neuroprotective effects of quercetin glycosides have also been reported, which are characterized by antagonizing changes in gene expression, such as Park2, Park5, Park7, Casp3, and Casp7 genes [142].

\section{Anti-Alzheimer's Disease Potential: In Vivo Studies on the Efficacy of Quercetin}

The protective effects of a diet rich in polyphenols have been reported in several pathologic conditions, such as cardiovascular diseases, metabolic disorders, infections, cancers, and neurodegenerative disorders. It has been reported in several studies that quercetin exerts 
neuroprotective effects when administered in vivo. It protects neuronal cells from oxidative stress induced by various chemicals and prevents hippocampal apoptosis [50,143]. Quercetin improves memory, learning, and cognitive functions, and all these effects have been shown to be associated with its antioxidant properties [144]. In vivo studies using mice as an animal model have supported that quercetin increases spatial memory tasks, and decreases $\beta$-amyloidosis, tauopathies, astrogliosis, and microgliosis by increasing AMPK activity and decreasing mitochondrial dysfunction [117,118].

Keddy et al. (2012) investigated the neuroprotective and anti-inflammatory effects of the flavonoids-enriched fraction containing quercetin and its glucosides in a mouse model of hypoxic-ischemic brain injury. The study had concluded that the repeated administration of the flavonoid-enriched fraction prior to an experimental stroke produced by hypoxic-ischemia prevents the neuronal loss in the striatum and dorsal hippocampus. Due to the low bioavailability of quercetin and its glucosides, it required injection through the intraperitonial or intravenous route to achieve neuroprotective effects [145]. Tota (2010) et al. studied the effects of quercetin on cerebral blood flow and memory impairment in mice and linked the ability of quercetin to increase cerebral blood flow and energy metabolism to its memory-enhancing effects [146]. After oral administration in humans, quercetin is extensively metabolized during its absorption from the gut, affecting its bioavailability. Clinical efficacy trials/studies of quercetin have yet to be carried out, which is likely given its low BBB penetrability [147]. Furthermore, the metabolites of quercetin have long half-lives in vivo, and repeated dosing may lead to plasma accumulation [145]. These are important factors, which will need to be considered in the design of quercetin analogs for clinical studies.

\section{Conclusions}

Quercetin is a flavonoid with notable pharmacological effects and promising therapeutic potential. It is widely distributed among plants and found commonly in our daily diet, such as in fruits and vegetables. It has beneficial properties against general mechanisms of AD etiology in a variety of in vitro and in vivo models. It protects neuronal cells by attenuating oxidative stress and neuroinflammation. The anti-Alzheimer's disease properties of quercetin include the inhibition of $\mathrm{A} \beta$ aggregation and tau phosphorylation. It restores acetylcholine levels through the inhibition of hydrolysis of acetylcholine by AChE enzyme. Although showing neuroprotective efficacy in several in vitro and animal models, in vivo studies have reported that it is extensively metabolized upon absorption from the gut, affecting its bioavailability. It also has low BBB penetrability, thus limiting its efficacy in combating neurodegenerative disorders. Therefore, future clinical trials of quercetin and its analogs as neuroprotective agents must improve its bioavailability, developing related molecules with greater gut and brain penetrability, which will likely improve clinical efficacy.

Funding: MA was supported in part by grants from the National Institutes of Environmental Health Sciences R01 ES10563, R01 ES07331 and R01 ES020852 (MA).

Conflicts of Interest: The authors declare that they have no conflict of interest.

\section{References}

1. DeTure, M.A.; Dickson, D.W. The neuropathological diagnosis of Alzheimer's disease. Mol. Neurodegener. 2019, 14, 1-18. [CrossRef] [PubMed]

2. Parent, M.J.; Zimmer, E.R.; Shin, M.; Kang, M.S.; Fonov, V.S.; Mathieu, A.; Aliaga, A.; Kostikov, A.; Do Carmo, S.; Dea, D. Multimodal imaging in rat model recapitulates Alzheimer's Disease biomarkers abnormalities. J. Neurosci. 2017, 37, 12263-12271. [CrossRef]

3. Kommaddi, R.P.; Das, D.; Karunakaran, S.; Nanguneri, S.; Bapat, D.; Ray, A.; Shaw, E.; Bennett, D.A.; Nair, D.; Ravindranath, V. A $\beta$ mediates F-actin disassembly in dendritic spines leading to cognitive deficits in Alzheimer's disease. J. Neurosci. 2018, 38, 1085-1099. [CrossRef]

4. Wallace, R.A.; Dalton, A.J. What can we learn from study of Alzheimer's disease in patients with Down syndrome for early-onset Alzheimer's disease in the general population? Alzheimer's Res. Ther. 2011, 3, 13. [CrossRef] 
5. Hollingworth, P.; Harold, D.; Jones, L.; Owen, M.J.; Williams, J. Alzheimer's disease genetics: Current knowledge and future challenges. Int. J. Geriatr. Psychiatry 2011, 26, 793-802. [CrossRef]

6. Mayeux, R.; Stern, Y. Epidemiology of Alzheimer disease. Cold Spring Harb. Perspect. Med. 2012, 2, a006239. [CrossRef]

7. Aliev, G.; Obrenovich, M.E.; Reddy, V.P.; Shenk, J.C.; Moreira, P.I.; Nunomura, A.; Zhu, X.; Smith, M.A.; Perry, G. Antioxidant therapy in Alzheimer's disease: Theory and practice. Mini Rev. Med. Chem. 2008, 8, 1395-1406. [CrossRef]

8. Rountree, S.D.; Chan, W.; Pavlik, V.N.; Darby, E.J.; Siddiqui, S.; Doody, R.S. Persistent treatment with cholinesterase inhibitors and/or memantine slows clinical progression of Alzheimer disease. Alzheimers Res. 2009, 1, 7. [CrossRef] [PubMed]

9. Kim, J.; Lee, H.J.; Lee, K.W. Naturally occurring phytochemicals for the prevention of Alzheimer's disease. J. Neurochem. 2010, 112, 1415-1430. [CrossRef] [PubMed]

10. Farooq, U.; Khan, A.; Naz, S.; Rauf, A.; Khan, H.; Khan, A.; Ullah, I.; Bukhari, S.M. Sedative and antinociceptive activities of two new sesquiterpenes isolated from Ricinus communis. Chin. J. Nat. Med. 2018, 16, 225-230. [CrossRef]

11. Jawad, M.; Khan, H.; Pervez, S.; Bawazeer, S.S.; Abu-Izneid, T.; Saeed, M.; Kamal, M.A. Pharmacological validation of the anxiolytic, muscle relaxant and sedative like activities of Capsicum annuum in animal model. Bangladesh J. Pharmacol. 2017, 12, 439-447. [CrossRef]

12. Karim, N.; Khan, I.; Khan, H.; Ayub, B.; Abdel-Halim, H.; Gavande, N. Anxiolytic potential of natural flavonoids. Sm J. Steroids Horm. 2018, 1, 1001.

13. Khan, H.; Marya; Amin, S.; Kamal, M.A.; Patel, S. Flavonoids as acetylcholinesterase inhibitors: Current therapeutic standing and future prospects. Biomed. Pharmacother. 2018, 101, 860-870. [CrossRef] [PubMed]

14. Nabavi, S.F.; Khan, H.; D’Onofrio, G.; Šamec, D.; Shirooie, S.; Dehpour, A.R.; Argüelles, S.; Habtemariam, S.; Sobarzo-Sanchez, E. Apigenin as neuroprotective agent: Of mice and men. Pharmacol. Res. 2018, 128, 359-365. [CrossRef] [PubMed]

15. Rengasamy, K.R.R.; Khan, H.; Gowrishankar, S.; Lagoa, R.J.L.; Mahomoodally, F.M.; Khan, Z.; Suroowan, S.; Tewari, D.; Zengin, G.; Hassan, S.T.S.; et al. The role of flavonoids in autoimmune diseases: Therapeutic updates. Pharmacol. Ther. 2019, 194, 107-131. [CrossRef]

16. Nabavi, S.F.; Atanasov, A.G.; Khan, H.; Barreca, D.; Trombetta, D.; Testai, L.; Sureda, A.; Tejada, S.; Vacca, R.A.; Pittalà, V.; et al. Targeting ubiquitin-proteasome pathway by natural, in particular polyphenols, anticancer agents: Lessons learned from clinical trials. Cancer Lett. 2018, 434, 101-113. [CrossRef]

17. Khan, H.; Ullah, H.; Martorell, M.; Valdes, S.E.; Belwal, T.; Tejada, S.; Sureda, A.; Kamal, M.A. Flavonoids nanoparticles in cancer: Treatment, prevention and clinical prospects. Semin. Cancer Biol. 2019, 1-13. [CrossRef]

18. Solanki, I.; Parihar, P.; Mansuri, M.L.; Parihar, M.S. Flavonoid-based therapies in the early management of neurodegenerative diseases. Adv. Nutr. Int. Rev. J. 2015, 6, 64-72. [CrossRef]

19. Devore, E.E.; Kang, J.H.; Breteler, M.; Grodstein, F. Dietary intakes of berries and flavonoids in relation to cognitive decline. Ann. Neurol. 2012, 72, 135-143. [CrossRef]

20. Gao, X.; Cassidy, A.; Schwarzschild, M.; Rimm, E.; Ascherio, A. Habitual intake of dietary flavonoids and risk of Parkinson disease. Neurology 2012, 78, 1138-1145. [CrossRef]

21. Ullah, H.; Khan, H. Anti-Parkinson potential of silymarin: Mechanistic insight and therapeutic standing. Front. Pharmacol. 2018, 9, 422. [CrossRef]

22. Baptista, F.I.; Henriques, A.G.; Silva, A.M.; Wiltfang, J.; da Cruz e Silva, O.A. Flavonoids as therapeutic compounds targeting key proteins involved in Alzheimer's disease. Acs Chem. Neurosci. 2014, 5, 83-92. [CrossRef] [PubMed]

23. Deng, Y.-H.; Wang, N.-N.; Zou, Z.-X.; Zhang, L.; Xu, K.-P.; Chen, A.F.; Cao, D.-S.; Tan, G.-S. Multi-Target Screening and Experimental Validation of Natural Products from Selaginella Plants against Alzheimer's Disease. Front. Pharmacol. 2017, 8, 539. [CrossRef] [PubMed]

24. Hamaguchi, T.; Ono, K.; Murase, A.; Yamada, M. Phenolic compounds prevent Alzheimer's pathology through different effects on the amyloid- $\beta$ aggregation pathway. Am. J. Pathol. 2009, 175, 2557-2565. [CrossRef] [PubMed]

25. Ayaz, M.; Ullah, F.; Sadiq, A.; Kim, M.O.; Ali, T. Natural Products-Based Drugs: Potential Therapeutics against Alzheimer's Disease and other Neurological Disorders. Front. Pharmacol. 2019, 10, 1417. [CrossRef] 
26. Maher, P. The potential of flavonoids for the treatment of neurodegenerative diseases. Int. J. Mol. Sci. 2019, 20, 3056. [CrossRef] [PubMed]

27. Kouhestani, S.; Jafari, A.; Babaei, P. Kaempferol attenuates cognitive deficit via regulating oxidative stress and neuroinflammation in an ovariectomized rat model of sporadic dementia. Neural Regen. Res. 2018, 13, 1827.

28. Brüll, V.; Burak, C.; Stoffel-Wagner, B.; Wolffram, S.; Nickenig, G.; Müller, C.; Langguth, P.; Alteheld, B.; Fimmers, R.; Naaf, S. Effects of a quercetin-rich onion skin extract on $24 \mathrm{~h}$ ambulatory blood pressure and endothelial function in overweight-to-obese patients with (pre-) hypertension: A randomised double-blinded placebo-controlled cross-over trial. Br. J. Nutr. 2015, 114, 1263-1277. [CrossRef]

29. Kim, D.H.; Khan, H.; Ullah, H.; Hassan, S.T.; Šmejkal, K.; Efferth, T.; Mahamoodally, M.F.; Xu, S.; Habtemariam, S.; Filosa, R. MicroRNA targeting by quercetin in cancer treatment and chemoprotection. Pharmacol. Res. 2019, 104346. [CrossRef]

30. Kawabata, K.; Mukai, R.; Ishisaka, A. Quercetin and related polyphenols: New insights and implications for their bioactivity and bioavailability. Food Funct. 2015, 6, 1399-1417. [CrossRef]

31. Harwood, M.; Danielewska-Nikiel, B.; Borzelleca, J.; Flamm, G.; Williams, G.; Lines, T. A critical review of the data related to the safety of quercetin and lack of evidence of in vivo toxicity, including lack of genotoxic/carcinogenic properties. Food Chem. Toxicol. 2007, 45, 2179-2205. [CrossRef] [PubMed]

32. Li, Y.; Yao, J.; Han, C.; Yang, J.; Chaudhry, M.T.; Wang, S.; Liu, H.; Yin, Y. Quercetin, Inflammation and Immunity. Nutrients 2016, 8, 167. [CrossRef]

33. Rishitha, N.; Muthuraman, A. Therapeutic evaluation of solid lipid nanoparticle of quercetin in pentylenetetrazole induced cognitive impairment of zebrafish. Life Sci. 2018, 199, 80-87. [CrossRef] [PubMed]

34. Li, X.; Wang, H.; Gao, Y.; Li, L.; Tang, C.; Wen, G.; Zhou, Y.; Zhou, M.; Mao, L.; Fan, Y. Protective effects of quercetin on mitochondrial biogenesis in experimental traumatic brain injury via the Nrf2 signaling pathway. PLoS ONE 2016, 11, e0164237. [CrossRef] [PubMed]

35. El-Horany, H.E.; El-latif, R.N.A.; ElBatsh, M.M.; Emam, M.N. Ameliorative effect of quercetin on neurochemical and behavioral deficits in rotenone rat model of Parkinson's disease: Modulating autophagy (quercetin on experimental Parkinson's disease). J. Biochem. Mol. Toxicol. 2016, 30, 360-369. [CrossRef] [PubMed]

36. Sandhir, R.; Mehrotra, A. Quercetin supplementation is effective in improving mitochondrial dysfunctions induced by 3-nitropropionic acid: Implications in Huntington's disease. Biochim. Et Biophys. Acta 2013, 1832, 421-430. [CrossRef] [PubMed]

37. Tsao, R.; McCallum, J. Chemistry of flavonoids. In Fruit and Vegetable Phytochemicals; De la Rosa, L.A., Alvarez-Parrilla, E., Gonzalez-Aguilar, G.A., Eds.; Wiley-Blackwell: Ames, IA, USA, 2010; pp. 131-153.

38. Aherne, S.A.; O'Brien, N.M. Dietary flavonols: Chemistry, food content, and metabolism. Nutrition 2002, 18, 75-81. [CrossRef]

39. Kumar, S.; Sharma, H.; Yadav, K. Quercetin and metabolic syndrome. EJPMR 2016, 3, 701-709.

40. Dall'Acqua, S.; Miolo, G.; Innocenti, G.; Caffieri, S. The photodegradation of quercetin: Relation to oxidation. Molecules 2012, 17, 8898-8907. [CrossRef]

41. Kim, H.P.; Son, K.H.; Chang, H.W.; Kang, S.S. Anti-inflammatory plant flavonoids and cellular action mechanisms. J. Pharmacol. Sci. 2004, 96, 229-245. [CrossRef] [PubMed]

42. Ganeshpurkar, A.; Saluja, A.K. The pharmacological potential of rutin. Saudi Pharm. J. 2017, 25, 149-164. [CrossRef] [PubMed]

43. Shi, Z.H.; Li, N.G.; Tang, Y.P.; Shi, Q.P.; Tang, H.; Li, W.; Zhang, X.; Fu, H.A.; Duan, J.A. Biological Evaluation and SAR Analysis of O-Methylated Analogs of Quercetin as Inhibitors of Cancer Cell Proliferation. Drug Dev. Res. 2014, 75, 455-462. [CrossRef] [PubMed]

44. Shi, Z.-H.; Li, N.-G.; Tang, Y.-P.; Yang, J.-P.; Duan, J.-A. Metabolism-based synthesis, biologic evaluation and SARs analysis of O-methylated analogs of quercetin as thrombin inhibitors. Eur. J. Med. Chem. 2012, 54, 210-222. [CrossRef] [PubMed]

45. Gliszczyńska-Świgło, A.; van der Woude, H.; de Haan, L.; Tyrakowska, B.; Aarts, J.M.; Rietjens, I.M. The role of quinone reductase (NQO1) and quinone chemistry in quercetin cytotoxicity. Toxicol. Vitr. 2003, 17, 423-431. [CrossRef]

46. Biasutto, L.; Marotta, E.; De Marchi, U.; Zoratti, M.; Paradisi, C. Ester-based precursors to increase the bioavailability of quercetin. J. Med. Chem. 2007, 50, 241-253. [CrossRef] 
47. Echeverry, C.; Arredondo, F.; Abin-Carriquiry, J.A.; Midiwo, J.O.; Ochieng, C.; Kerubo, L.; Dajas, F. Pretreatment with natural flavones and neuronal cell survival after oxidative stress: A structure- activity relationship study. J. Agric. Food Chem. 2010, 58, 2111-2115. [CrossRef]

48. Jaimand, K.; Rezaee, M.B.; Behrad, Z.; Najafy-Ashtiany, A. Comparison of extraction and measurement of quercetin from stigma, style, sepals, petals and stamen of Crocus sativus by HPLC in combination with heat and ultrasonic. J. Med. Plants By-Prod. 2012, 1, 167-170.

49. Alok, S.; Jain, S.K.; Verma, A.; Kumar, M.; Mahor, A.; Sabharwal, M. Herbal antioxidant in clinical practice: A review. Asian Pac. J. Trop. Biomed. 2014, 4, 78-84. [CrossRef]

50. Costa, L.G.; Garrick, J.M.; Roquè, P.J.; Pellacani, C. Mechanisms of neuroprotection by quercetin: Counteracting oxidative stress and more. Oxidative Med. Cell. Longev. 2016, 2016, 1-10. [CrossRef]

51. Choudhary, M.; Kumar, V.; Malhotra, H.; Singh, S. Medicinal plants with potential anti-arthritic activity. J. Intercult. Ethnopharmacol. 2015, 4, 147. [CrossRef]

52. Zhou, T.-S.; Zhou, R.; Yu, Y.-B.; Xiao, Y.; Li, D.-H.; Xiao, B.; Yu, O.; Yang, Y.-J. Cloning and characterization of a flavonoid 3'-hydroxylase gene from tea plant (Camellia sinensis). Int. J. Mol. Sci. 2016, 17, 261. [CrossRef]

53. Thakur, D.; Das, S.; Sabhapondit, S.; Tamuly, P.; Deka, D. Antimicrobial Activities of Tocklai Vegetative Tea Clones. Indian J. Microbiol. 2011, 51, 450-455. [CrossRef]

54. Henagan, T.; Cefalu, W.; Ribnicky, D.; Noland, R.; Dunville, K.; Campbell, W.; Stewart, L.; Forney, L.; Gettys, T.; Chang, J. In vivo effects of dietary quercetin and quercetin-rich red onion extract on skeletal muscle mitochondria, metabolism, and insulin sensitivity. Genes Nutr. 2015, 10, 2. [CrossRef]

55. Oliveira, T.T.; Campos, K.M.; Cerqueira-Lima, A.T.; Carneiro, T.C.B.; da Silva Velozo, E.; Melo, I.C.A.R.; Figueiredo, E.A.; de Jesus Oliveira, E.; de Vasconcelos, D.F.S.A.; Pontes-de-Carvalho, L.C. Potential therapeutic effect of Allium cepa L. and quercetin in a murine model of Blomia tropicalis induced asthma. Daru J. Pharm. Sci. 2015, 23, 18. [CrossRef] [PubMed]

56. Gondi, M.; Rao, U.P. Ethanol extract of mango (Mangifera indica L.) peel inhibits $\alpha$-amylase and $\alpha$-glucosidase activities, and ameliorates diabetes related biochemical parameters in streptozotocin (STZ)-induced diabetic rats. J. Food Sci. Technol. 2015, 52, 7883-7893. [CrossRef] [PubMed]

57. Leone, A.; Spada, A.; Battezzati, A.; Schiraldi, A.; Aristil, J.; Bertoli, S. Cultivation, genetic, ethnopharmacology, phytochemistry and pharmacology of Moringa oleifera leaves: An overview. Int. J. Mol. Sci. 2015, 16, 12791-12835. [CrossRef] [PubMed]

58. Saini, R.K.; Sivanesan, I.; Keum, Y.-S. Phytochemicals of Moringa oleifera: A review of their nutritional, therapeutic and industrial significance. 3 Biotech. 2016, 6, 203. [CrossRef]

59. Oliveira, A.P.; Costa, R.M.; Magalhães, A.S.; Pereira, J.A.; Carvalho, M.; Valentão, P.; Andrade, P.B.; Silva, B.M. Targeted metabolites and biological activities of Cydonia oblonga Miller leaves. Food Res. Int. 2012, 46, 496-504. [CrossRef]

60. Apati, P.; Szentmihályi, K.; Balázs, A.; Baumann, D.; Hamburger, M.; Kristó, T.S.; Szőke, É.; Kéry, Á. HPLC analysis of the flavonoids in pharmaceutical preparations from Canadian goldenrod (Solidago canadensis). Chromatographia 2002, 56, S65-S68. [CrossRef]

61. Huang, W.-y.; Zhang, H.-c.; Liu, W.-x.; Li, C.-y. Survey of antioxidant capacity and phenolic composition of blueberry, blackberry, and strawberry in Nanjing. J. Zhejiang Univ. Sci. B 2012, 13, 94-102. [CrossRef]

62. Roopchand, D.E.; Kuhn, P.; Rojo, L.E.; Lila, M.A.; Raskin, I. Blueberry polyphenol-enriched soybean flour reduces hyperglycemia, body weight gain and serum cholesterol in mice. Pharmacol. Res. 2013, 68, 59-67. [CrossRef] [PubMed]

63. Altaf, R.; Asmawi, M.Z.B.; Dewa, A.; Sadikun, A.; Umar, M.I. Phytochemistry and medicinal properties of Phaleria macrocarpa (Scheff.) Boerl. extracts. Pharmacogn. Rev. 2013, 7, 73. [CrossRef] [PubMed]

64. Kaur, T.; Hussain, K.; Koul, S.; Vishwakarma, R.; Vyas, D. Evaluation of nutritional and antioxidant status of Lepidium latifolium Linn.: A novel phytofood from Ladakh. PLoS ONE 2013, 8, e69112. [CrossRef] [PubMed]

65. Gupta, S.M.; Singh, S.; Pandey, P.; Grover, A.; Ahmed, Z. Semi-quantitative analysis of transcript accumulation in response to drought stress by Lepidium latifolium seedlings. Plant. Signal. Behav. 2013, 8, e25388. [CrossRef] [PubMed]

66. Srivastava, M.; Hegde, M.; Chiruvella, K.K.; Koroth, J.; Bhattacharya, S.; Choudhary, B.; Raghavan, S.C. Sapodilla plum (Achras sapota) induces apoptosis in cancer cell lines and inhibits tumor progression in mice. Sci. Rep. 2014, 4, 6147. [CrossRef] [PubMed] 
67. Street, R.A.; Sidana, J.; Prinsloo, G. Cichorium intybus: Traditional uses, phytochemistry, pharmacology, and toxicology. Evid. Based Complement. Altern. Med. 2013, 2013. [CrossRef]

68. Bovy, A.; Schijlen, E.; Hall, R.D. Metabolic engineering of flavonoids in tomato (Solanum lycopersicum): The potential for metabolomics. Metabolomics 2007, 3, 399. [CrossRef] [PubMed]

69. Newcomb, R.D.; Crowhurst, R.N.; Gleave, A.P.; Rikkerink, E.H.; Allan, A.C.; Beuning, L.L.; Bowen, J.H.; Gera, E.; Jamieson, K.R.; Janssen, B.J. Analyses of expressed sequence tags from apple. Plant. Physiol. 2006, 141, 147-166. [CrossRef] [PubMed]

70. Manela, N.; Oliva, M.; Ovadia, R.; Sikron-Persi, N.; Ayenew, B.; Fait, A.; Galili, G.; Perl, A.; Weiss, D.; Oren-Shamir, M. Phenylalanine and tyrosine levels are rate-limiting factors in production of health promoting metabolites in Vitis vinifera cv. Gamay Red cell suspension. Front. Plant Sci. 2015, 6, 538. [CrossRef]

71. Esatbeyoglu, T.; Ewald, P.; Yasui, Y.; Yokokawa, H.; Wagner, A.E.; Matsugo, S.; Winterhalter, P.; Rimbach, G. Chemical characterization, free radical scavenging, and cellular antioxidant and anti-inflammatory properties of a stilbenoid-rich root extract of Vitis vinifera. Oxidative Med. Cell. Longev. 2016, 2016, 8591286. [CrossRef]

72. Boussahel, S.; Speciale, A.; Dahamna, S.; Amar, Y.; Bonaccorsi, I.; Cacciola, F.; Cimino, F.; Donato, P.; Ferlazzo, G.; Harzallah, D. Flavonoid profile, antioxidant and cytotoxic activity of different extracts from Algerian Rhamnus alaternus L. bark. Pharmacogn. Mag. 2015, 11, S102. [PubMed]

73. Aman, U.; Subhan, F.; Shahid, M.; Akbar, S.; Ahmad, N.; Ali, G.; Fawad, K.; Sewell, R.D. Passiflora incarnata attenuation of neuropathic allodynia and vulvodynia apropos GABA-ergic and opioidergic antinociceptive and behavioural mechanisms. BMC Complement. Altern. Med. 2016, 16, 77. [CrossRef] [PubMed]

74. Khan, H.; Saeed, M.; Khan, M.A.; Muhammad, N.; Ghaffar, R. Isolation of long-chain esters from the rhizome of Polygonatum verticillatum by potent tyrosinase inhibition. Med. Chem. Res. 2013, 22, 2088-2092. [CrossRef]

75. Król, E.; Jeszka-Skowron, M.; Krejpcio, Z.; Flaczyk, E.; Wójciak, R.W. The effects of supplementary Mulberry leaf (Morus alba) extracts on the trace element status $(\mathrm{Fe}, \mathrm{Zn}$ and $\mathrm{Cu}$ ) in relation to diabetes management and antioxidant indices in diabetic rats. Biol. Trace Elem. Res. 2016, 174, 158-165. [CrossRef] [PubMed]

76. Shepperd, W.D. Ginkgo biloba L.: Ginkgo. In The Woody Plant Seed Manual; Agricultural Handbook No. 727; Bonner, F.T., Karrfalt, R.P., Eds.; Department of Agriculture, Forest Service: Washington, DC, USA, 2008; pp. 559-561.

77. Chan, P.-C.; Xia, Q.; Fu, P.P. Ginkgo biloba leave extract: Biological, medicinal, and toxicological effects. J. Environ. Sci. Health C Environ. Carcinog. Ecotoxicol. Rev. 2007, 25, 211-244. [CrossRef] [PubMed]

78. Oliveira, A.I.; Pinho, C.; Sarmento, B.; Dias, A.C. Neuroprotective activity of Hypericum perforatum and its major components. Front. Plant Sci. 2016, 7, 1004. [CrossRef]

79. Benedek, B.; Kopp, B. Achillea millefolium L. sl revisited: Recent findings confirm the traditional use. Wien. Med. Wochenschr. 2007, 157, 312-314. [CrossRef]

80. Cai, X.; Fang, Z.; Dou, J.; Yu, A.; Zhai, G. Bioavailability of quercetin: Problems and promises. Curr. Med. Chem. 2013, 20, 2572-2582. [CrossRef]

81. Ader, P.; Wessmann, A.; Wolffram, S. Bioavailability and metabolism of the flavonol quercetin in the pig. Free Radic. Biol. Med. 2000, 28, 1056-1067. [CrossRef]

82. Moon, Y.J.; Wang, L.; DiCenzo, R.; Morris, M.E. Quercetin pharmacokinetics in humans. Biopharm. Drug Dispos. 2008, 29, 205-217. [CrossRef]

83. Day, A.J.; Mellon, F.; Barron, D.; Sarrazin, G.; Morgan, M.R.; Williamson, G. Human metabolism of dietary flavonoids: Identification of plasma metabolites of quercetin. Free Radic. Res. 2001, 35, 941-952. [CrossRef] [PubMed]

84. Youdim, K.A.; Qaiser, M.Z.; Begley, D.J.; Rice-Evans, C.A.; Abbott, N.J. Flavonoid permeability across an in situ model of the blood-brain barrier. Free Radic. Biol. Med. 2004, 36, 592-604. [CrossRef] [PubMed]

85. Youdim, K.A.; Dobbie, M.S.; Kuhnle, G.; Proteggente, A.R.; Abbott, N.J.; Rice-Evans, C. Interaction between flavonoids and the blood-brain barrier: In vitro studies. J. Neurochem. 2003, 85, 180-192. [CrossRef] [PubMed]

86. Kroemer, H.K.; Klotz, U. Glucuronidation of drugs. Clin. Pharmacokinet. 1992, 23, 292-310. [CrossRef]

87. Kawai, Y.; Nishikawa, T.; Shiba, Y.; Saito, S.; Murota, K.; Shibata, N.; Kobayashi, M.; Kanayama, M.; Uchida, K.; Terao, J. Macrophage as a target of quercetin glucuronides in human atherosclerotic arteries implication in the anti-atherosclerotic mechanism of dietary flavonoids. J. Biol. Chem. 2008, 283, 9424-9434. [CrossRef] 
88. Moore, B.D.; Chakrabarty, P.; Levites, Y.; Kukar, T.L.; Baine, A.-M.; Moroni, T.; Ladd, T.B.; Das, P.; Dickson, D.W.; Golde, T.E. Overlapping profiles of A $\beta$ peptides in the Alzheimer's disease and pathological aging brains. Alzheimer's Res. Ther. 2012, 4, 18. [CrossRef]

89. Swomley, A.M.; Förster, S.; Keeney, J.T.; Triplett, J.; Zhang, Z.; Sultana, R.; Butterfield, D.A. Abeta, oxidative stress in Alzheimer disease: Evidence based on proteomics studies. Biochim. Et Biophys. Acta 2014, 1842, 1248-1257. [CrossRef]

90. Revett, T.J.; Baker, G.B.; Jhamandas, J.; Kar, S. Glutamate system, amyloid $\beta$ peptides and tau protein: Functional interrelationships and relevance to Alzheimer disease pathology. J. Psychiatry Neurosci. 2013, 38, 6. [CrossRef]

91. Dawkins, E.; Small, D.H. Insights into the physiological function of the $\beta$-amyloid precursor protein: Beyond Alzheimer's disease. J. Neurochem. 2014, 129, 756-769. [CrossRef]

92. Teich, A.F.; Arancio, O. Is the amyloid hypothesis of Alzheimer's disease therapeutically relevant? Biochem. J. 2012, 446, 165-177. [CrossRef]

93. Chow, V.W.; Mattson, M.P.; Wong, P.C.; Gleichmann, M. An overview of APP processing enzymes and products. Neuromolecular Med. 2010, 12, 1-12. [CrossRef] [PubMed]

94. Šimić, G.; Babić Leko, M.; Wray, S.; Harrington, C.; Delalle, I.; Jovanov-Milošević, N.; Bažadona, D.; Buée, L.; De Silva, R.; Di Giovanni, G. Tau protein hyperphosphorylation and aggregation in Alzheimer's disease and other tauopathies, and possible neuroprotective strategies. Biomolecules 2016, 6, 6. [CrossRef] [PubMed]

95. Piedrahita, D.; Hernández, I.; López-Tobón, A.; Fedorov, D.; Obara, B.; Manjunath, B.; Boudreau, R.L.; Davidson, B.; LaFerla, F.; Gallego-Gómez, J.C. Silencing of CDK5 reduces neurofibrillary tangles in transgenic alzheimer's mice. J. Neurosci. 2010, 30, 13966-13976. [CrossRef]

96. Nelson, P.T.; Alafuzoff, I.; Bigio, E.H.; Bouras, C.; Braak, H.; Cairns, N.J.; Castellani, R.J.; Crain, B.J.; Davies, P.; Tredici, K.D. Correlation of Alzheimer disease neuropathologic changes with cognitive status: A review of the literature. J. Neuropathol. Exp. Neurol. 2012, 71, 362-381. [CrossRef] [PubMed]

97. Liu, C.-C.; Zhao, N.; Yamaguchi, Y.; Cirrito, J.R.; Kanekiyo, T.; Holtzman, D.M.; Bu, G. Neuronal heparan sulfates promote amyloid pathology by modulating brain amyloid- $\beta$ clearance and aggregation in Alzheimer's disease. Sci. Transl. Med. 2016, 8, ra44-ra332. [CrossRef] [PubMed]

98. Butterfield, D.A.; Swomley, A.M.; Sultana, R. Amyloid $\beta$-peptide (1-42)-induced oxidative stress in Alzheimer disease: Importance in disease pathogenesis and progression. Antioxid. Redox Signal. 2013, 19, 823-835. [CrossRef]

99. Butterfield, D.A.; Di Domenico, F.; Barone, E. Elevated risk of type 2 diabetes for development of Alzheimer disease: A key role for oxidative stress in brain. Biochim. Et Biophys. Acta 2014, 1842, 1693-1706. [CrossRef]

100. Petersen, R.C.; Lopez, O.; Armstrong, M.J.; Getchius, T.S.; Ganguli, M.; Gloss, D.; Gronseth, G.S.; Marson, D.; Pringsheim, T.; Day, G.S. Practice guideline update summary: Mild cognitive impairment: Report of the Guideline Development, Dissemination, and Implementation Subcommittee of the American Academy of Neurology. Neurology 2018, 90, 126-135. [CrossRef]

101. García-Escudero, V.; Martín-Maestro, P.; Perry, G.; Avila, J. Deconstructing mitochondrial dysfunction in Alzheimer disease. Oxidative Med. Cell. Longev. 2013, 2013. [CrossRef]

102. Hardas, S.S.; Sultana, R.; Clark, A.M.; Beckett, T.L.; Szweda, L.I.; Murphy, M.P.; Butterfield, D.A. Oxidative modification of lipoic acid by HNE in Alzheimer disease brain. Redox Biol. 2013, 1, 80-85. [CrossRef]

103. Yan, M.H.; Wang, X.; Zhu, X. Mitochondrial defects and oxidative stress in Alzheimer disease and Parkinson disease. Free Radic. Biol. Med. 2013, 62, 90-101. [CrossRef]

104. Heneka, M.T.; Carson, M.J.; El Khoury, J.; Landreth, G.E.; Brosseron, F.; Feinstein, D.L.; Jacobs, A.H.; Wyss-Coray, T.; Vitorica, J.; Ransohoff, R.M. Neuroinflammation in Alzheimer's disease. Lancet Neurol. 2015, 14, 388-405. [CrossRef]

105. De Strooper, B.; Karran, E. The cellular phase of Alzheimer's disease. Cell 2016, 164, 603-615. [CrossRef] [PubMed]

106. Frank-Cannon, T.C.; Alto, L.T.; McAlpine, F.E.; Tansey, M.G. Does neuroinflammation fan the flame in neurodegenerative diseases? Mol. Neurodegener. 2009, 4, 47. [CrossRef] [PubMed]

107. Ray, R.; Juranek, J.K.; Rai, V. RAGE axis in neuroinflammation, neurodegeneration and its emerging role in the pathogenesis of amyotrophic lateral sclerosis. Neurosci. Biobehav. Rev. 2016, 62, 48-55. [CrossRef] [PubMed] 
108. Ahmed, T.; Zahid, S.; Mahboob, A.; Mehpara Farhat, S. Cholinergic system and post-translational modifications: An insight on the role in Alzheimer's disease. Curr. Neuropharmacol. 2017, 15, 480-494. [CrossRef] [PubMed]

109. Savonenko, A.V.; Melnikova, T.; Hiatt, A.; Li, T.; Worley, P.F.; Troncoso, J.C.; Wong, P.C.; Price, D.L. Alzheimer's therapeutics: Translation of preclinical science to clinical drug development. Neuropsychopharmacology 2012, 37, 261-277. [CrossRef]

110. Caruana, M.; Cauchi, R.; Vassallo, N. Putative role of red wine polyphenols against brain pathology in Alzheimer's and Parkinson's disease. Front. Nutr. 2016, 3, 31. [CrossRef]

111. Jantan, I.; Ahmad, W.; Bukhari, S.N.A. Plant-derived immunomodulators: An insight on their preclinical evaluation and clinical trials. Front. Plant Sci. 2015, 6, 655. [CrossRef]

112. Figueira, I.; Menezes, R.; Macedo, D.; Costa, I.; Nunes dos Santos, C. Polyphenols beyond barriers: A glimpse into the brain. Curr. Neuropharmacol. 2017, 15, 562-594. [CrossRef]

113. Ay, M.; Luo, J.; Langley, M.; Jin, H.; Anantharam, V.; Kanthasamy, A.; Kanthasamy, A.G. Molecular mechanisms underlying protective effects of quercetin against mitochondrial dysfunction and progressive dopaminergic neurodegeneration in cell culture and MitoPark transgenic mouse models of Parkinson's Disease. J. Neurochem. 2017, 141, 766-782. [CrossRef] [PubMed]

114. David, A.V.A.; Arulmoli, R.; Parasuraman, S. Overviews of biological importance of quercetin: A bioactive flavonoid. Pharmacogn. Rev. 2016, 10, 84.

115. Khan, M.T.H.; Orhan, I.; Şenol, F.; Kartal, M.; Şener, B.; Dvorská, M.; Šmejkal, K.; Šlapetová, T. Cholinesterase inhibitory activities of some flavonoid derivatives and chosen xanthone and their molecular docking studies. Chem. Biol. Interact. 2009, 181, 383-389. [CrossRef] [PubMed]

116. Shimmyo, Y.; Kihara, T.; Akaike, A.; Niidome, T.; Sugimoto, H. Flavonols and flavones as BACE-1 inhibitors: Structure-activity relationship in cell-free, cell-based and in silico studies reveal novel pharmacophore features. Biochim. Et Biophys. Acta 2008, 1780, 819-825. [CrossRef]

117. Sabogal-Guáqueta, A.M.; Munoz-Manco, J.I.; Ramírez-Pineda, J.R.; Lamprea-Rodriguez, M.; Osorio, E.; Cardona-Gómez, G.P. The flavonoid quercetin ameliorates Alzheimer's disease pathology and protects cognitive and emotional function in aged triple transgenic Alzheimer's disease model mice. Neuropharmacology 2015, 93, 134-145. [CrossRef]

118. Wang, D.-M.; Li, S.-Q.; Wu, W.-L.; Zhu, X.-Y.; Wang, Y.; Yuan, H.-Y. Effects of long-term treatment with quercetin on cognition and mitochondrial function in a mouse model of Alzheimer's disease. Neurochem. Res. 2014, 39, 1533-1543. [CrossRef]

119. Richetti, S.; Blank, M.; Capiotti, K.; Piato, A.; Bogo, M.; Vianna, M.; Bonan, C. Quercetin and rutin prevent scopolamine-induced memory impairment in zebrafish. Behav. Brain Res. 2011, 217, 10-15. [CrossRef]

120. Regitz, C.; Marie Dußling, L.; Wenzel, U. Amyloid-beta (A $\beta 1-42)$-induced paralysis in Caenorhabditis elegans is inhibited by the polyphenol quercetin through activation of protein degradation pathways. Mol. Nutr. Food Res. 2014, 58, 1931-1940. [CrossRef]

121. Jiménez-Aliaga, K.; Bermejo-Bescós, P.; Benedí, J.; Martín-Aragón, S. Quercetin and rutin exhibit antiamyloidogenic and fibril-disaggregating effects in vitro and potent antioxidant activity in APPswe cells. Life Sci. 2011, 89, 939-945. [CrossRef]

122. Porat, Y.; Abramowitz, A.; Gazit, E. Inhibition of amyloid fibril formation by polyphenols: Structural similarity and aromatic interactions as a common inhibition mechanism. Chem. Biol. Drug Des. 2006, 67, 27-37. [CrossRef]

123. Sato, M.; Murakami, K.; Uno, M.; Nakagawa, Y.; Katayama, S.; Akagi, K.-i.; Masuda, Y.; Takegoshi, K.; Irie, K. Site-specific inhibitory mechanism for amyloid $\beta 42$ aggregation by catechol-type flavonoids targeting the Lys residues. J. Biol. Chem. 2013, 288, 23212-23224. [CrossRef] [PubMed]

124. Paris, D.; Mathura, V.; Ait-Ghezala, G.; Beaulieu-Abdelahad, D.; Patel, N.; Bachmeier, C.; Mullan, M. Flavonoids lower Alzheimer's A $\beta$ production via an NFKB dependent mechanism. Bioinformation 2011, 6 , 229. [CrossRef] [PubMed]

125. Jiang, W.; Luo, T.; Li, S.; Zhou, Y.; Shen, X.-Y.; He, F.; Xu, J.; Wang, H.-Q. Quercetin protects against okadaic acid-induced injury via MAPK and PI3K/Akt/GSK3 $\beta$ signaling pathways in HT22 hippocampal neurons. PLoS ONE 2016, 11, e0152371. [CrossRef] [PubMed] 
126. Abdalla, F.H.; Schmatz, R.; Cardoso, A.M.; Carvalho, F.B.; Baldissarelli, J.; de Oliveira, J.S.; Rosa, M.M.; Nunes, M.A.G.; Rubin, M.A.; da Cruz, I.B. Quercetin protects the impairment of memory and anxiogenic-like behavior in rats exposed to cadmium: Possible involvement of the acetylcholinesterase and $\mathrm{Na}+\mathrm{K}+-\mathrm{ATPase}$ activities. Physiol. Behav. 2014, 135, 152-167. [CrossRef]

127. Abdalla, F.H.; Cardoso, A.M.; Pereira, L.B.; Schmatz, R.; Gonçalves, J.F.; Stefanello, N.; Fiorenza, A.M.; Gutierres, J.M.; da Silva Serres, J.D.; Zanini, D. Neuroprotective effect of quercetin in ectoenzymes and acetylcholinesterase activities in cerebral cortex synaptosomes of cadmium-exposed rats. Mol. Cell. Biochem. 2013, 381, 1-8. [CrossRef]

128. Ademosun, A.O.; Oboh, G.; Bello, F.; Ayeni, P.O. Antioxidative properties and effect of quercetin and its glycosylated form (Rutin) on acetylcholinesterase and butyrylcholinesterase activities. J. Evid. Based Complement. Altern. Med. 2016, 21, NP11-NP17. [CrossRef]

129. Baldissarelli, J.; Santi, A.; Schmatz, R.; Abdalla, F.H.; Cardoso, A.M.; Martins, C.C.; Dias, G.R.M.; Calgaroto, N.S.; Pelinson, L.P.; Reichert, K.P. Hypothyroidism enhanced ectonucleotidases and acetylcholinesterase activities in rat synaptosomes can be prevented by the naturally occurring polyphenol quercetin. Cell. Mol. Neurobiol. 2017, 37, 53-63. [CrossRef]

130. Jung, M.; Park, M. Acetylcholinesterase inhibition by flavonoids from Agrimonia pilosa. Molecules 2007, 12, 2130-2139. [CrossRef]

131. Kennedy, M.A.; Moffat, T.C.; Gable, K.; Ganesan, S.; Niewola-Staszkowska, K.; Johnston, A.; Nislow, C.; Giaever, G.; Harris, L.J.; Loewith, R. A signaling lipid associated with Alzheimer's disease promotes mitochondrial dysfunction. Sci. Rep. 2016, 6, 19332. [CrossRef]

132. Lee, J.; Jo, D.-G.; Park, D.; Chung, H.Y.; Mattson, M.P. Adaptive cellular stress pathways as therapeutic targets of dietary phytochemicals: Focus on the nervous system. Pharmacol. Rev. 2014, 66, 815-868. [CrossRef]

133. Butterfield, D.A. The 2013 discovery award from the society for free radical biology and medicine: Selected discoveries from the Butterfield Laboratory of Oxidative Stress and its sequelae in brain in cognitive disorders exemplified by Alzheimer disease and chemotherapy induced cognitive impairment. Free Radic. Biol. Med. 2014, 157. [CrossRef]

134. Lakhanpal, P.; Rai, D.K. Quercetin: A versatile flavonoid. Internet J. Med. Update 2007, 2, 22-37. [CrossRef]

135. Testa, G.; Gamba, P.; Badilli, U.; Gargiulo, S.; Maina, M.; Guina, T.; Calfapietra, S.; Biasi, F.; Cavalli, R.; Poli, G. Loading into nanoparticles improves quercetin's efficacy in preventing neuroinflammation induced by oxysterols. PLoS ONE 2014, 9, e96795. [CrossRef] [PubMed]

136. Kim, B.-W.; Koppula, S.; Park, S.-Y.; Hwang, J.-W.; Park, P.-J.; Lim, J.-H.; Choi, D.-K. Attenuation of inflammatory-mediated neurotoxicity by Saururus chinensis extract in LPS-induced BV-2 microglia cells via regulation of NF-KB signaling and anti-oxidant properties. BMC Complement. Altern. Med. 2014, 14, 502. [CrossRef] [PubMed]

137. Qureshi, A.A.; Tan, X.; Reis, J.C.; Badr, M.Z.; Papasian, C.J.; Morrison, D.C.; Qureshi, N. Inhibition of nitric oxide in LPS-stimulated macrophages of young and senescent mice by $\delta$-tocotrienol and quercetin. Lipids Health Dis. 2011, 10, 239. [CrossRef] [PubMed]

138. Davis, J.M.; Murphy, E.A.; Carmichael, M.D. Effects of the dietary flavonoid quercetin upon performance and health. Curr. Sports Med. Rep. 2009, 8, 206-213. [CrossRef]

139. Belo, D.; André, C.; Lucho, A.P.d.B.; Vinadé, L.; Rocha, L.; Seibert França, H.; Marangoni, S.; Rodrigues-Simioni, L. In vitro antiophidian mechanisms of Hypericum brasiliense choisy standardized extract: Quercetin-dependent neuroprotection. Biomed Res. Int. 2013, 2013, 943520.

140. Ansari, M.A.; Abdul, H.M.; Joshi, G.; Opii, W.O.; Butterfield, D.A. Protective effect of quercetin in primary neurons against $A \beta$ (1-42): Relevance to Alzheimer's disease. J. Nutr. Biochem. 2009, 20, 269-275. [CrossRef]

141. West, S.; Bhugra, P. Emerging drug targets for $A \beta$ and tau in Alzheimer's disease: A systematic review. Br. J. Clin. Pharmacol. 2015, 80, 221-234. [CrossRef]

142. Magalingam, K.B.; Radhakrishnan, A.; Ramdas, P.; Haleagrahara, N. Quercetin glycosides induced neuroprotection by changes in the gene expression in a cellular model of Parkinson's disease. J. Mol. Neurosci. 2015, 55, 609-617. [CrossRef]

143. Dong, Y.-s.; Wang, J.-1.; Feng, D.-y.; Qin, H.-z.; Wen, H.; Yin, Z.-m.; Gao, G.-d.; Li, C. Protective effect of quercetin against oxidative stress and brain edema in an experimental rat model of subarachnoid hemorrhage. Int. J. Med. Sci. 2014, 11, 282. [CrossRef] 
144. Singh, S.K.; Srivastav, S.; Yadav, A.K.; Srikrishna, S.; Perry, G. Overview of Alzheimer's disease and some therapeutic approaches targeting $\mathrm{A} \beta$ by using several synthetic and herbal compounds. Oxidative Med. Cell. Longev. 2016, 2016, 7361613. [CrossRef] [PubMed]

145. Keddy, P.G.; Dunlop, K.; Warford, J.; Samson, M.L.; Jones, Q.R.; Rupasinghe, H.V.; Robertson, G.S. Neuroprotective and anti-inflammatory effects of the flavonoid-enriched fraction AF4 in a mouse model of hypoxic-ischemic brain injury. PLOS ONE 2012, 7, e51324. [CrossRef] [PubMed]

146. Tota, S.; Awasthi, H.; Kamat, P.K.; Nath, C.; Hanif, K. Protective effect of quercetin against intracerebral streptozotocin induced reduction in cerebral blood flow and impairment of memory in mice. Behav. Brain Res. 2010, 209, 73-79. [CrossRef] [PubMed]

147. Ossola, B.; Kääriäinen, T.M.; Männistö, P.T. The multiple faces of quercetin in neuroprotection. Expert Opin. Drug Saf. 2009, 8, 397-409. [CrossRef]

(C) 2019 by the authors. Licensee MDPI, Basel, Switzerland. This article is an open access article distributed under the terms and conditions of the Creative Commons Attribution (CC BY) license (http://creativecommons.org/licenses/by/4.0/). 